DOI https://doi.org/10.30525/978-9934-26-004-9-3

\title{
THE PROSPECTS OF DEVELOPMENT OF BUSINESS COMMUNICATION
}

\author{
Gostieva O. V. \\ Postgraduate Student at the Art and Humanities Department \\ of the the Faculty of Art and Design \\ International Humanitarian University \\ Odesa, Ukraine
}

The development of communication technologies has resulted in total transformation of business culture.

In the sphere of media theory some authors express the idea that political mechanisms are determined by the images of mass-information seen by people, and that, by displacing other forms of culture, they establish economic and political mechanisms.

Cultural determinism is the paradigm used by a lot of researchers.

There is a range of theories of social progress describing culture as a factor that determines everything else. They are different from theories of economic determinism because the role of an individual or class in the means of production generates their look on the world and cultural roles. Political trends existing within the realm of cultural determinism, as a rule, oppose to political and economic ideologies or treat them as less important compared to some other factors, such as religion, for instance.

Considering this, the American futurist and sociologist A. Toffler describes problems that the mankind will have to face. The writer emphasizes that we see the amazing signs of psychic disorder, when people feel shattered and disoriented, caused by partially dimmed consciousness: increase of drug abuse, popularized mysticism, periodic outbreaks of vandalism and spontaneous violence, policy of nihilism and nostalgic attitude to tyranny, painful apathy of millions of people. Toffler states that the majority of social problems can be better understood if the above mentioned phenomena are linked to the notion of the Future Shock [1, p. 90]. Looking at the reasons for essential social, individual, psychological, and informational impact on the mankind, Toffler speaks like a fervent technological determinist.

Technological determinism is one of the main and most popular theories devoted to complicated interrelation between a person and the artificial world, e.i. objects, technology and abstract notions made by a human, and, in their turn, determining his/her acts, way of living and further development. [1, p. 338]. 
$\mathrm{He}$ assumed that there will be developing interaction between communication technologies and a consumer. A variety of life styles might derive as a result of the intellectual revolution. It implied that the mode of communication would be transferred from the real time to the virtual world.

Consequently, there definitely will be some new terms that will be quickly assimilated by young scientists and researchers. Here we can mention and explain a number of such terms.

Agile - used as a synonym of «flexible», in business it is understood as the quality of being capable of showing tolerance in making decisions, able to analyze changeable circumstances and react to these changes.

In corporate culture (policy) it means the team's responsibility for taking a decision and for the result.

Any changes in the terms occur immediately, so it is important to be oriented to reality, opportunity, people, and company. There are also several factors among which we can name:

- interaction culture

- policy, growth and development of the company

- culture of project supervision

- culture of competence.

Some other common terms are the following:

- Teambuilding - creating a team and corporate management.

- Flash mob - a planned action of a group of people who assemble suddenly in a public place and perform for a brief time.

- Deadline - a particular date or time by which one has to complete and present a project.

- Life hack - a usually simple and clever tip, method for accomplishing a task more easily and efficiently, making the process less complicated. Also it may mean information that simplifies life and optimizes living.

- Point de repere -from French - landmark, point of reference, in marketing this term is used to refer to the beginning of a process.

- Downshifting - the practice of giving up the pursuit of someone else's goals in order to live you own life and get more satisfaction (e.g. leaving a well-paid job that is difficult and doing something that gives less stress).

- Name-dropping - ( or «throwing the names»), the practice of constantly mentioning influential people's names, or names of organizations, brandnames, special terms in conversations in order to sound more important and powerful.

- Troubleshooting - a form of problem solving, often applied to failed products, systems, processes. In a wider understanding, troubleshooting is a technique of optimizing or modernizing any process.

A lot of scholars have been using another term for more than 100 years: simulacrum. 
The term «simulacrum (pl. simulacra)» was coined by the French philosopher Georges Bataille, and was also used by Jean Baudrillard for the analysis of economic relations and interpretation of the surrounding world reality.

Jean Baudrillard explained simulacra as copies, pseudo-objects which replace reality with post-reality by means of simulation (imitation). So, a simulacrum is a copy, an image that has no original (or even never had it), an interpretation of something that does not really exist [2, p. 251].

Baudrillard stated that modern society substituted the real-world and its sense for symbols and signs, and the whole experience of the mankind is imitation of the reality. The simulacra are not the reflection of reality, more than that, they are not even its deceptive images. They are neither based on real life nor conceal or disguise it, they hide the fact that nothing in the existing reality is relevant of our currently present understanding of the real world [3, p. 11].

The images of simulative communication emerge via various informational streams which determine the ways of interactive contacts with reality:

- Advertising life-style;

- Image and brand.

And if simulative objects contain their originals, simulacra lose their value. The peculiarities of all these actions result in the pattern of simulative communication: falsification - production - simulation.

Taking all the above mentioned facts into consideration, we can conclude that business-communication is linked to the origins of business relations that should be built, maintained and developed; it comprises all forms of professional communication which enable corporations to carry out efficient co-operation with the surrounding environment by means of information exchange.

\section{References:}

1. Тоффлер Э. Шок будущего = Future Shock, 1970. - М.: ACT, 2008. -560 c.

2. Бодрийяр Ж. Символический обмен и смерть / Ж. Бодрийяр. - М.: Добросвет, 2000. - 387 с.

3. Бодрийяр Ж. Симулякры и симуляции. - М. : Изд. «Постум» $2016,-240$ c. 